\title{
Project-Based Learning Model in the Development of Students' Creativity in Physical Education
}

\section{Learning}

\author{
Tite Juliantine*, Oom Rohmah, Lilis Komariyah, Agus Gumilar and Burhan Hambali \\ Physical Education Department \\ Universitas Pendidikan Indonesia \\ Bandung, Indonesia \\ *titejuliantine@upi.edu
}

\begin{abstract}
This study aims to implement the Project Based Learning model in developing students' creativity in Physical Education learning. The methodology used in this study is a quasi-experimental design with pre-test post-test only group design. The participants of this research are junior high school students in the city of Bandung. The instrument used in this research is creativity questionnaire that is developed by researchers guided by Guilford which includes aptitude traits and non-aptitude traits. All data generated in this study will be analysed using the paired sample $t$ test analysis technique with the aim to see the effect of the Project Based Learning model in the development of student creativity seen from the comparison of pre-test and post-test scores after the intervention is given. The analysis shows that the Project Based Learning model has an influence on the development of student creativity. This is proved by obtaining the results of the analysis with a magnitude of $p$ value of $0.00(0.00<0.05)$.
\end{abstract}

Keywords: creativity, project-based learning, physical education

\section{INTRODUCTION}

In the context of human resource development, education as a conscious effort is aimed to develop the students' potentials that can be manifested in the form of abilities, skills, attitudes, and personalities that are in accordance with the objectives of national education. Rusli Lutan explained that changes in knowledge, attitudes and skills as a consequent factor of education are considered as human capital [1]. In order to demonstrate the function of education as a way to develop human resources, it is necessary to develop a constructive learning environment which stimulates the creativity of the students so that new innovative ideas can be developed.

Creativity has a very important role in people's lives. Through their creativity, people can give meaning to their lives. As reviewed in several subjects, the need to develop creativity is a very critical issue. Wahyudin argued that creativity is the ability to produce something new and original that can be manifested in the form of ideas, tools, and to be more specific, creativity is a skill to discover something new (inventiveness) [2].
Alan J. Rowe explained that creativity focuses on our way of thinking and our desire to achieve something new or different [3]. Dedi Supriadi explained that creativity is a person's ability to produce something new, both in the form of ideas and real work, which is relatively different from what has been done before [4]. Another opinion, Winardi argued that creativity involves solving one's mental curiosity in a particular field which results in the creation or discovery of new things [5]. Meanwhile, Munandar defined creativity as an ability which reflects the fluency, flexibility, and originality in thinking, and the ability to elaborate (develop, enrich, detail) an idea [6]. In addition, Reynold Bean argued that creativity is the process which allows a person to express his basic nature through a form or medium in order to create satisfaction within himself or herself; in other word, to produce a product that communicates something about that person to others [7].

The importance of creativity that is linked to education is important in various countries. In Japan, the development of creativity is considered as the most important goal of education for the 21st century [8]. In Singapore, creativity is listed in the main curriculum as a skill and a core value in learning [9]. In China, creativity has been an important component of education since 2001 and its development has become a "priority" [10]. In Hong Kong, the proposal of education policy includes creativity as "higher-order thinking skills" [11].

One of the efforts that can be done to develop creativity is through the application of learning models. There are many learning models that can be applied in Physical Education. However, the authors thought that there is one learning model that can enhance students' creativity that is called project-based learning.

.Project Based-Learning is a learning model which involves project work and provides an opportunity for teachers to manage learning activity in the classroom. Furthermore, the project work applied in this model consists of complex tasks that are based on challenging questions and problems, and this requires students to design, solve problems, make decisions, investigate, and provide opportunities for students to work independently [12]. 
Project-based learning allows students to research, plan, design, and reflect on their creativity in technology projects [13]. The teacher must actively find the ways to understand students' conceptions, suggest alternative conceptions, stimulate curiosity among students, and develop classroom assignments that lead to the construction of knowledge [14].

Discovery Learning is a learning model that is based on inquiry (inquiry based), constructivist and theory of how to learn. The learning model that is provided to students enables them to solve actual problems and encourage them to solve their own problems. Since this is a constructivist approach, in solving their problems, students tend to use their previous experience in solving the problems. Their activities are done by interacting to explore, questioning during experimenting with trial and error techniques [15].

Discovery Learning Method equals to understanding the concepts, meanings, and relationships, through an intuitive process to finally arrive at a conclusion. In the learning concept, the actual Discovery Learning method is the construction of categories or concepts, which could make generalizations. As Bruner's suggested in his theory of categorization that appears in a discovery, discovery is the creation of categories, or more commonly known as coding systems [15].

Problems that often arise during the physical education learning process become a strong issue related to the application of learning models that tend to be less attractive. This is caused by many factors, one of them is student creativity tends to decrease during the learning process; therefore, this research has a strategic value to support the results of previous research, and can be a new scientific reference in the context of problem solving in the Physical Education learning process. In addition, this study will have an impact on testing problem-based learning models on the development of student creativity in physical education so that the results that are obtained can support the results of previous research.

\section{METHOD}

The methodology that is used in this study is a quasiexperimental design method with pre-test post-test only group design $[16,17]$. The use of the experimental method is used because it is assumed that basically the main goal of this study is to implement the Project Based-Learning model in the development of student creativity in Physical Education learning. The researchers apply this research to Kartika Candra High School students with random sampling that refers to a random cluster $[16,17]$.

The instrument used in this research is a creativity questionnaire in the form of a questionnaire that is developed by the researchers themselves from several expert references. Therefore, the questionnaire is arranged with the following lines:
TABLE I. STUDENTS' CREATIVITY TEST [5,6,18]

\begin{tabular}{|l|l|}
\hline \multicolumn{1}{|c|}{ Sub Variable } & \multicolumn{1}{c|}{ Indicator } \\
\hline \multirow{4}{*}{ Aptitude } & Fluidity \\
\cline { 2 - 3 } & Flexibility \\
\cline { 2 - 3 } & Originality \\
\cline { 2 - 3 } & Elaboration \\
\cline { 2 - 3 } & Evaluation \\
\hline \multirow{5}{*}{ Non Aptitude } & Curiosity \\
\cline { 2 - 2 } & Imaginative \\
\cline { 2 - 2 } & Challenged by diversity \\
\cline { 2 - 2 } & Dare to take a rist \\
\cline { 2 - 2 } & Respect \\
\hline
\end{tabular}

\section{RESULTS AND DISCUSSION}

A. Results

TABLE II. PAIRED SAMPLE T TEST

\begin{tabular}{|c|c|c|c|c|c|c|}
\hline & \multicolumn{3}{|c|}{ Paired Differences } & \multirow[t]{2}{*}{$\mathbf{t}$} & \multirow[t]{2}{*}{ df } & \multirow{2}{*}{$\begin{array}{l}\text { Sig. (2- } \\
\text { tailed) }\end{array}$} \\
\hline & Mean & $S D$ & $\begin{array}{l}S E \\
M\end{array}$ & & & \\
\hline $\begin{array}{l}\text { Pre PBL - } \\
\text { Post PBL }\end{array}$ & $(31.62)$ & $\begin{array}{l}5.1 \\
4\end{array}$ & $\begin{array}{l}0.7 \\
3\end{array}$ & $\begin{array}{l}(43.4 \\
6)\end{array}$ & $\begin{array}{l}49.0 \\
0\end{array}$ & 0.00 \\
\hline
\end{tabular}

Based on the results of the analysis demonstrated in table 2, the $\mathrm{t}$ value is 43.46 and become significant at $\mathrm{p}_{\text {_value }} 0.00$ $(0.00<0.05)$. This data indicates that there is a difference between the initial measurement score and the final measurement score in the PBL group. The final test measurement scores tend to be higher than the scores on the initial test measurements. Therefore, there was a significant improvement in the PBL group after treatment was applied. Thus, it can be concluded that the project based learning model influences the development of student creativity.

TABLE III. THE RESUlT OF INDEPENDENT SAMPLES TeST

\begin{tabular}{|c|c|c|c|c|c|c|c|c|}
\hline \multicolumn{2}{|c|}{} & \multicolumn{2}{|c|}{$\begin{array}{c}\text { Levene's Test } \\
\text { for Equality } \\
\text { of Variances }\end{array}$} & \multicolumn{5}{|c|}{ t-test for Equality of Means } \\
\cline { 2 - 8 } & F & Sig. & $t$ & $d f$ & Sig. & MD & $\begin{array}{c}\text { Std. } \\
\text { Error }\end{array}$ \\
\hline $\begin{array}{c}\text { Cre } \\
\text { ativi } \\
\text { ty }\end{array}$ & $\begin{array}{c}\text { Equal } \\
\text { variance } \\
\text { s } \\
\text { assumed }\end{array}$ & 23.92 & 0.00 & 33. & 98. & 0.00 & 55.32 & 1.63 \\
\cline { 2 - 9 } & $\begin{array}{c}\text { Equal } \\
\text { variance } \\
\text { s not } \\
\text { assumed }\end{array}$ & & & 89 & 00 & & & \\
\hline
\end{tabular}

Table 3 shows the results of a comparison analysis between two averages with an unpaired group. This analysis aims to see the comparison of two averages between PBL groups in the development of student creativity in Physical Education learning. The results of the analysis as demonstrated in table 4.7 shows that the $t$ value that is obtained is 33.89 and it is significant at p_value $0.00(0.00<0.05)$. Because the value of p_value is proven to be smaller than $\alpha(0.00<0.05)$, it means 
[5] Winardi, Kreativitas dan Teknik-teknik Pemikiran Kreatif dalam Bidang Manajemen, Bandung: Citra Aditya Bakti, 1991.

[6] U. Munandar, Pengembangan emosi dan kreativitas, Jakarta: Rineka Cipta, 2004.

[7] R. Bean, Cara Mengembangkan Kreativitas Anak, Binarupa. Aksara, 1995.

[8] S. O'Donnell and C. Micklethwaite, Arts and creativity in education: An international perspective, 1999. Retrieved from: www.inca.or g.uk/pdf/1999_creativity_and_arts.pdf

[9] INCA, Primary education: An international perspective, 2009. Retrieved from: www.inca.org.uk/pdf/probe_singapore.pdf

[10] K. Vong, "Developing creativity and promoting social harmony: The relationship between government, school and parents' perceptions of children's creativity in Macao-SAR in China," Early Years, vol. 28, pp. 149-158, 2008.

[11] M. Fryer, Creativity across the curriculum: A review and analysis of programmes designed to develop creativity, QCA, 2003

[12] J.W. Thomas, A review of research on project-based learning, 2000.

[13] Y. Doppelt and M. Barak, "Pupils Identify Key Aspects and Outcomes of a Technological Learning Environment," Journal of Technology Studies, vol. 28(1), pp. 22-28, 2002.

[14] E. Duckworth, The having of wonderful ideas and other essays on teaching and learning, Teachers College Press, 2006

[15] J.S. Bruner, "Going beyond the information given. In University of Colorado, Boulder, Department of Psychology (Ed.)," Contemporary approaches to cognition, pp. 218-238, 1957.

[16] B. Johnson and L. Christensen, Qualitative research. Educational research: Quantitative, qualitative, and mixed approaches, 2012, pp. 375-408.

[17] W.P. Astuti, A.P.B Prasetyo, and E.S. Rahayu, "Pengembangan Instrumen Asesmen Autentik Berbasis Literasi Sains pada Materi Sistem Ekskresi,” Lembaran Ilmu Kependidikan, vol. 41(1), 2012.

[18] J.P. Guilford, “Creativity,” American Psychologist, vol. 5, pp. 444-454, 1950.

[19] J. Hiebert and T.P. Carpenter, Learning and teaching with understanding, Handbook of research on mathematics teaching and learning: A project of the National Council of Teachers of Mathematics, pp. 65-97, 1992 .

[3] A.J. Rowe, Creative Intelligence: Discovering the Innovative Potential
[3] in Ourselves and Others, Upper Saddle River, NJ: FT Press, 2004.

[4] D. Supriadi,Kreativitas Kebudayaan dan Perkembangan IPTEK, Banudng: Alfabeta, 1994. 